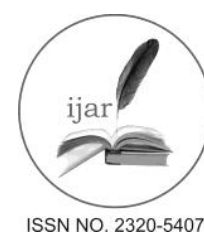

Journal homepage: http://www.journalijar.com

Journal DOI: $\underline{10.21474 / I J A R 01}$

INTERNATIONAL JOURNAL

OF ADVANCED RESEARCH

RESEARCH ARTICLE

\title{
A COMPARATIVE STUDY OF THE ADJUSTMENT PROBLEM OF CHILDREN OF THE WORKING AND NON - WORKING MOTHERS.
}

\author{
Dr. S. K. Panda ${ }^{1}$, Ms. Pramila Nagar ${ }^{2}$.
}

1. Asst. Prof. in Education, Army Institute of Education, Greater Noida, UP.

2. Student, Noida College of Physical Education, Noida, UP.

\section{Manuscript Info}

Abstract

Manuscript History:

Received: 17 March 2016

Final Accepted: 02 May 2016

Published Online: May 2016

Key words:

*Corresponding Author

Dr. S. K. Panda.

Copy Right, IJAR, 2016,. All rights reserved.

\section{Introduction:-}

In a country where woman are worshipped as 'deities' having supreme powers, there does not seem to have been a perceptible changes in the status in of women, even after more than sixty years of independence. Through there are evidences of women enjoying a high status in the society in the Vedic times, gradually down the ages, they come to be treated as second-class citizens, with almost no rights, no education and no role the background in maledominated society.

Our civilization, our customs, our laws, have all made by men and he was taken good care of keep himself in a superior position to treat women as the chattel and a play-thing to by exploded for his own advantages and amusement. Under this continuous presser women has been unable to grow and dew has capacities to her fullest. Women were expected to work at home and this was considered to be the most essential work for the substance of life to her generation. Even women accepted home work as their fate and as their life. This work did not fetch them any status expects some reference of respect and gratitude. Hence, all along the history of humanity, they were considered as backward, without 'mind' or 'soul'.

In most of civilization men taken every advantage of the usually sup strength of her biological superiority. With the passage of time various sociologists and scholars recognise women's rights and advocated higher education for the women themselves started demanding that they should no longer be treated as cloth to be alternately patched and ignored but should be considered as human being with minds to be cultivated, bodies to be exercised, natural apparition to recognised and satisfied. Now the techno social changes, the economic needs, the constitutional provisions of various others factors help women not only to accept gainful employment but also to enter it to occupation and profession previously monopolized by man.

In the today modern world the spread of education made the women to get more knowledge, more thinking power. After independence our constitution made the provision under Act 15(1), 16(1) that shall not discriminate against 
citizen on ground of religion, race, caste, sex, place or birth or any of them. Now women's role is not just limited to home but it is extended outside the home also. From the earlier 'savitri image' Indian society has now accepted the working women image. A wife is a person who binds the four walls of a house to make it a home. She is an Ardhangini which just not only mean half of husband's body but a soul mate. She shares his responsibility despair and happiness. A working wife not only adds the income but also shoulders the responsibility, with the husband to provide the family a better life. She relieves the psychological tensions of our husband.

Every person in the world has problems and troubles but he react differently. One person reacts in an easy way and tries to find out the solution of the problem while other tries to escape the problem or fell rejected.

\section{Adjustment:-}

The term adjustment refers to a harmonious relation between the person and the environment. The degree of harmony depends upon two things: (i) Certain potentialities within a person and (ii) Character of the environment. In simple words adjustment is an all inclusive term meaning relation between an individual and his environment, through which has needs are satisfied in accordance with social demands. The adjustment process is a universal sequence that can can be identified in the behaviour of organism from lowest species to man.

An individual need to change or modify himself in some way or the other for fit in to or accommodate himself with his environment. As the conditions in the environment as changing all the time, adjustment is also a continuous process for instance, if a girl from the city married to a rural family and has to live in a village, she would have to change for her behaviour her habits and her attitude in order to accommodated herself to the changed environment.

\section{Statements of the problem:-}

A comparative study of the adjustment problem of children of the working and non - working mothers.

\section{Operational definition;-}

Adjustment:-

The term adjustment refers to a harmonious relationship between the person and the environment.

\section{Working women:-}

The women who are working in service or who come out of their homes for employment with the down of liberty and equality as safeguarded in the constitution.

\section{Non working women:-}

The women who are not in service and are not engaged in any commercial activities and are engaged primarily in household duties are called non - working women.

\section{Objectives of the study:-}

* To study the adjustment problems of children of working and non-working mothers.

* To compare the adjustment problems of male and female children of working mothers.

* To compare the adjustment problems of male and female children of non-working mothers.

* To compare the adjustment problems of male children of working and non-working mothers.

* To compare the adjustment problems of female children of working and non-working mothers.

\section{Hypotheses of the study:-}

In order to achieve these objectives, the following hypotheses were constructed:

* There is no significant difference between adjustment problems of children of working and non-working mothers.

* There is no significant difference between adjustment problems of male and female children of working mothers.

* There is no significant difference between adjustment problems of male and female children of non-working mothers.

* There is no significant difference between adjustment problems of male children of working and non-working mothers.

* There is no significant difference between adjustment problems of female children of working and non-working mothers 
Delimitations of the study:-

* The study was delimited to two hundred male and female students.

* The study was delimited to secondary level students only.

* The study was delimited to working mother and non working mother only.

* The study was delimited to Gurgaon district of Haryana.

\section{Sample:-}

A sample of two hundreds male and female children of VIII standard from the four schools of Gurgaon District was taken. Out of these 100 students were of working mothers and 100 were of non-working mothers.

\section{Method}

The investigator used the Descriptive Survey Method for the collection for the data.

\section{Tools used:-}

The Researcher was used Adjustment Inventory developed by A. K. Singla and R. P. Singh in the research study.

Analysis and conclusions:-

Table No 1:-Adjustment Problems of Children of Working and Non-working Mothers

\begin{tabular}{|l|c|c|c|c|l|}
\hline & $\mathrm{N}$ & $\mathrm{M}$ & $\mathrm{SD}$ & ' $\mathrm{t}$ ' test & \multicolumn{1}{c|}{$\begin{array}{c}\text { Level of } \\
\text { Significance }\end{array}$} \\
\hline Children of Working Mothers & 100 & 13.36 & 6.66 & .77 & Not Sign. \\
\hline Children of Non-Working Mothers & 100 & 12.67 & 6.97 & & \\
\hline
\end{tabular}

It was hypothesized there is no significations difference between adjustments problems of children of working and non-working mothers. On the basis of analysis and interpretation of data, it was found that there is no significant difference in adjustments problems between the children of working mothers and non-working mothers. Thus, the researcher was accepted the null hypothesis. It concludes that the children of working mothers and non-working mothers have similar adjustment problems. It means working conditions of mothers do not affect the feeling of her kids.

Table No 2:-Adjustment Problems of Male and Female Children of Working Mothers

\begin{tabular}{|l|c|c|c|c|l|}
\hline Children of Working Mothers & N & M & SD & 't' test & $\begin{array}{c}\text { Level of } \\
\text { Significance }\end{array}$ \\
\hline Male & 50 & 13.9 & 6.55 & .98 & Not Sign. \\
\hline Female & 50 & 12.6 & 6.75 & & \\
\hline
\end{tabular}

It was hypothesized that there is no significance difference between adjustment problems of male and female children of working mothers. After analysis and interpretation of data, the result was found not significant and the hypothesis was accepted. It concludes that there is no significant difference in adjustment problems among male and female children of working mothers. Both male and female children of working mothers have similar feeling conditions.

Table No 3:-Adjustment Problems of Male and Female Children of Non-working Mothers

\begin{tabular}{|l|c|c|c|c|l|}
\hline Children of Non-working Mothers & $\mathrm{N}$ & $\mathrm{M}$ & $\mathrm{SD}$ & ' $\mathrm{t}$ ' test & $\begin{array}{c}\text { Level of } \\
\text { Significance }\end{array}$ \\
\hline Male & 50 & 12.64 & 7.33 & .14 & Not Sign. \\
\hline Female & 50 & 12.46 & 5.39 & & \\
\hline
\end{tabular}

It was hypothesized that there is no significance difference between adjustment problems of male and female children of non-working mothers. After the analysis and interpretation of data, it was found that there is no significance difference between adjustment problems of male and female children of non-working mothers. Thus, the researcher was accepted the null hypothesis. It means both male and female children of non-working mothers have similar feeling condition. 
Table No 4:-Adjustment Problems of Male Children of Working and Non-working Mothers

\begin{tabular}{|l|c|c|c|c|c|}
\hline & $\mathrm{N}$ & $\mathrm{M}$ & $\mathrm{SD}$ & 't' test & $\begin{array}{c}\text { Level of } \\
\text { Significance }\end{array}$ \\
\hline Male Children of Working Mothers & 50 & 13.9 & 6.54 & \multirow{2}{*}{.91} & Not Sign. \\
\cline { 1 - 5 } $\begin{array}{l}\text { Male Children of Non-working } \\
\text { Mothers }\end{array}$ & 50 & 7.33 & 7.33 & \\
\hline
\end{tabular}

It was hypothesized that there is no significance difference between adjustment problems of male children of working and non-working mothers. After the analysis and interpretation of data; it was found that there is no significance difference between adjustment problems of male children of working and non-working mothers. Thus, the researcher was accepted the null hypothesis. It was concluded that male children of working mothers and nonworking mothers have similar conditions.

Table No 4:- Adjustment Problems of Female Children of Working and Non-working Mothers

\begin{tabular}{|l|c|c|c|c|c|}
\hline & $\mathrm{N}$ & $\mathrm{M}$ & $\mathrm{SD}$ & 't' test & $\begin{array}{c}\text { Level of } \\
\text { Significance }\end{array}$ \\
\hline Female Children of Working Mothers & 50 & 12.6 & 6.75 & \multirow{2}{*}{.11} & Not Sign. \\
\cline { 1 - 4 } $\begin{array}{l}\text { Female Children of Non- working } \\
\text { Mothers }\end{array}$ & 50 & 12.46 & 5.39 & & \\
\hline
\end{tabular}

It was hypothesized that there is no significance difference between adjustment problems of female children of working and non-working mothers in relation to security and adjustment. After analysis and interpretation of data, the result was found there is no significance difference between adjustment problems of female children of working and non-working mothers in relation to security and adjustment. Thus, the researcher was accepted the null hypothesis. It concluded that female children of working mothers and non-working mothers have similar conditions.

\section{References:-}

1. Goswami, S. (2007). Female Infanticide and Child Marriage, New Delhi: Rawat Publication.

2. Pathak, R. P. (2012). Development and Problems of Indian Education, New Delhi: Pearson.

3. Taj, H. (2008). Current Challenges in Education, New Delhi: Neelkamal Publications Pvt. Ltd.

4. Venkataiab, S. (2001). Education, Culture and Society, New Delhi: Anmol Publications Pvt. Ltd. 